\title{
Interactions between Symphonies and Film Music in the Euvre of László Lajtha
}

\author{
Viktória OzsvárT \\ Institute of Musicology \\ Research Centre for the Humanities \\ Hungarian Academy of Sciences \\ Táncsics Mihály u. 7, H-1014 Budapest, Hungary \\ E-mail: ozsvart.viktoria@btk.mta.hu
}

(Received: January 2017; accepted: March 2017)

\begin{abstract}
In the case of Hungarian composer and ethnomusicologist László Lajtha (1892-1963) discovering the manifold potentials in a symphonic orchestra linked strongly with the composition of works for stage and screen. Nevertheless, it clearly makes sense to examine the long-term relations Lajtha had with the film as a genre, by searching for common features in the structure of his music composed for films and his symphonies. Much of the musical material in Lajtha's Third Symphony is similar to those he used in his 1948 film music for Murder in the Cathedral. The similarity gains more complexity if one takes into consideration that the Third Symphony was marked by the composer as the starting point in a monumental, five-fold symphonic cycle composed through the 1950s. The article makes an attempt to explore the thematic and motivic relationship between the Third Symphony, the Variations and the film score Murder in the Cathedral by analysing the musical material and the structure, and by searching for correlation between the audible and visual effects of the music Lajtha used in the movie scenes. This kind of examination may offer a new perspective on the sources of inspiration that shaped Lajtha's workmanship and it also gives some important information about his way of thinking about music.
\end{abstract}

Keywords: László Lajtha, T. S. Eliot, Georg Hoellering, film music, symphony, musical structure

Browsing the œuvre of the Hungarian composer László Lajtha reveals a trend: only chamber music and solo piano works feature in the 69 compositions he wrote up to the 1930s. The first use Lajtha made of a symphonic orchestra was in 1931 
for his Violin Concerto op. 15. ${ }^{1}$ That score is lost and there are no signs of orchestral work from his student days either; nothing certain can be learned of any early symphonic style. The first extant symphonic piece is a ballet, Lysistrata op. 19, composed in 1933 to a libretto by Lajos Áprily based on the homonymous comedy by the Greek writer Aristophanes (first played in 411 BC). Lajtha was 41 years old at the time, so we might say that his interest in the symphony orchestra developed quite late. Also telling is that his first symphonic piece is a stage work, a ballet. The Hungarian musicologist Emöke Tari Solymosi writes in her doctoral thesis that this is "of great importance" in the case of a composer whose largest group of orchestral pieces consists of nine symphonies. ${ }^{2}$ János Breuer, in a book written and published for the centenary of Lajtha's birth, remarks that the orchestral apparatus of Lysistrata is rather lighter than usual for a symphonic work and bears a resemblance to the more transparent instrumentation typical of chamber music. This Breuer sees as a conscious advance in Lajtha's working methods, as if he were studying step by step how to make use of a symphony orchestra. ${ }^{3}$ Table 1 outlines his growing interest in symphonism, on which he would focus in his late creative period, from 1945 to 1963.

Learning how to exploit the potentials of an orchestral apparatus takes time. One has to be sure about the main traits of the instruments - their range of sound, varieties of timbre and other technical questions indispensable to finding the technique most appropriate for the artistic expression. With Lajtha, discovering the manifold potentials in a symphony orchestra linked strongly with composing works for stage and screen. Thus it makes sense to examine the long-term relations Lajtha had with the film as a genre, by searching for common features in the structure of his music composed for films and his symphonies. For example, much of the musical material in Lajtha's Third Symphony resembles his 1948 film music for Murder in the Cathedral. The similarity gains more complexity if one takes into consideration that the Third Symphony was marked by the composer as the starting point in a monumental, five-fold symphonic cycle composed through the $1950 \mathrm{~s}^{4}$ The thematic and motivic relationship between them points to the firm connection between these pieces in the composer's workmanship: the symphonies

1. Lajtha may have had to compose orchestral pieces in his student years, but if so, no documents or concert programs of them survive.

2. Emőke Tari Solymosi, Lajtha László színpadi müvei. Egy ismeretlen mücsoport a szerzői életút kontextusában [László Lajtha's works for the stage. An unknown set of works in the context of his career], (PhD Diss., Budapest: Liszt Academy of Music, 2011), 59.

3. János Breuer, Fejezetek Lajtha Lászlóról [Chapters from the life of László Lajtha] (Budapest: Editio Musica, 1992), 137.

4. According to Lajtha, he regarded his Symphonies nos. 3, 5, 7, 8, and 9 as a single unit, a tragic cycle, although he only recognized their unity after finishing his last symphony, the Ninth. The five works have much in common, e.g. similar thematic and motivic materials, similar topoi. So to an extent they can all be connected also to Lajtha's film score Murder in the Cathedral. Symphonies nos. 1 and 2 arose in another era, while nos. 4 and 6 were differently inspired. On this issue see, for example, Zsuzsanna Erdélyi, A kockás füzet [The checkered notebook], ed. Emőke Tari Solymosi (Budapest: Hagyományok Háza, 2010), passim, but especially 56-57. 
TABLE 1 Lajtha's works for symphony orchestra

\begin{tabular}{|l|l|l|l|}
\hline Opus no. & Title & Date of composition & Genre \\
\hline Op. 19 & Lysistrata & 1933 & Ballet \\
\hline Op. 19a & Lysistrata Suite & 1933 & Orchestral suite \\
\hline Op. 19b & Overture to Lysistrata & 1933 & Symphonic overture \\
\hline Op. 21 & Hortobágy & 1935 & Film music \\
\hline Op. 21a & Hortobágy Suite & 1935 & Orchestral suite \\
\hline Op. 24 & Symphony no. 1 & 1936 & Symphony \\
\hline Op. 25 & Divertissement no. 1 & 1936 & Orchestral suite \\
\hline Op. 27 & Symphony no. 2 & 1938 & Symphony \\
\hline Op. 30 & Divertissement no. 2 & 1939 & Orchestral suite \\
\hline Op. 35 & In memoriam & 1941 & Piece for orchestra \\
\hline Op. 38 & The Grove of the Four Gods & 1943 & Ballet \\
\hline Op. 38a & Suite no. 2 & 1943 & Orchestral suite \\
\hline Op. 39 & Capriccio & 1944 & Ballet \\
\hline Op. 39a & Suite from Capriccio & 1944 & Orchestral suite \\
\hline Op. 44 & Variations “Les Tentations & $1947-1948$ & Variations \\
\hline Op. 45 & Symphony no. 3 & 1948 & Symphony \\
\hline Op. 45a & Murder in the Cathedral & $1947-1948$ & Film music \\
\hline Op. 48 & Shapes and Forms & 1949 & Film music \\
\hline Op. 52 & Symphony no. 4 & 1951 & Symphony \\
\hline Op. 55 & Symphony no. 5 & 1952 & Symphony \\
\hline Op. 56 & Suite no. 3 & 1952 & Orchestral suite \\
\hline Op. 61 & Symphony no. 6 & 1955 & Symphony \\
\hline- & Stones, Castles, Men & 1956 & Film music \\
\hline Op. 63 & Symphony no. 7 & Symphony \\
\hline Op. 66 & Symphony no. 8 & Symphony \\
\hline Op. 67 & Symphony no. 9 & Symphony \\
\hline & & & \\
\hline
\end{tabular}

as absolute music and the film music as a kind of programmatic genre. To discover their common roots and outline their common characteristics calls for deeper insight into Lajtha's acquaintanceship with film.

The first time Lajtha tackled film music was between 1934 and 1936, when he was commissioned by the film director Georg Hoellering to compose music for a film entitled Hortobágy. ${ }^{5}$ It was named after a grassland steppe or puszta in Eastern Hungary. Apart from its geographical status as the largest stretch of natural grassland in Europe, since 1999 listed as an UNESCO World Heritage Site, the Hortobágy is abundant in iconic Hungarian cultural symbols. It was not by chance that Hoellering made the Hortobágy the setting for a documentary film about the life of Hungarian peasants. Strange though it may seem, the project took a marked

5. On relations between Lajtha and Hoellering, see Emőke Tari Solymosi, "Motion Picture as the 'Musical Play of the Future'. Lajtha, Höllering and Eliot," Hungarian Review 3/3 (May 2012), 81-93. Also available online under <http://www.hungarianreview.com/print/motion_picture_as_the_musical> (accessed 02/25/17). 
Example 1a Hortobágy Suite, mov. 2, 4 before 33

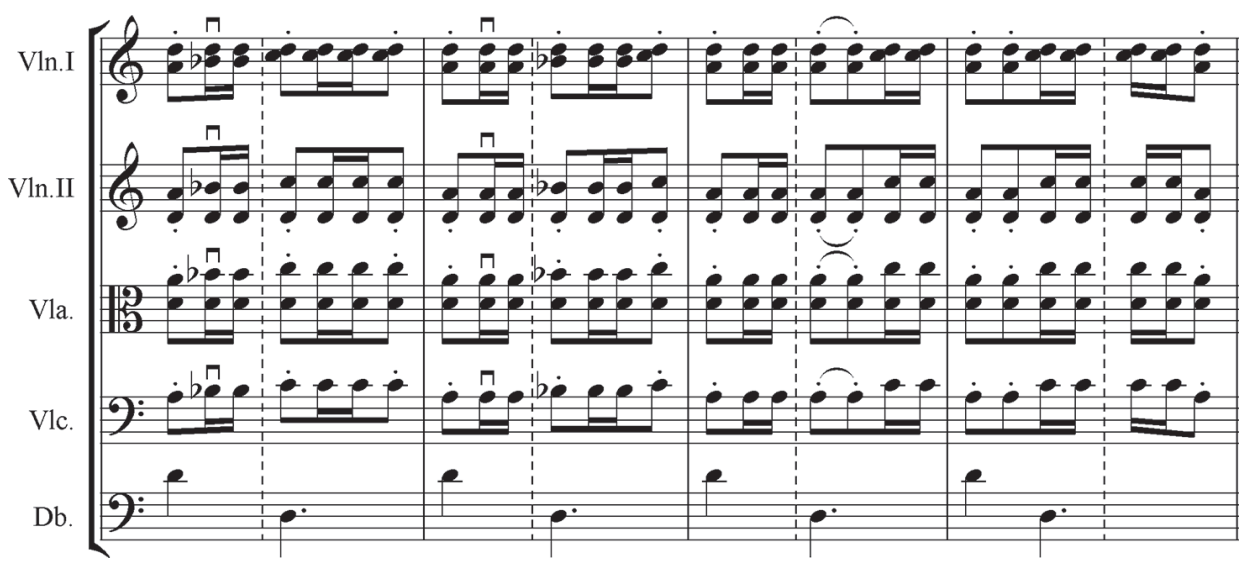

turn when he showed his film recordings to the well-known Hungarian writer and novelist Zsigmond Móricz, who was so deeply inspired as to base on them a short story entitled "Komor Ló."6 After its completion, Hoellering regarded it as a plot and asked Béla Bartók if he would compose the music for the film. Bartók pleaded other engagements and recommended Lajtha instead. ${ }^{7}$ Before accepting, Lajtha gathered information on the style and outlook of the film, not wishing to contribute to a work that falsified or unjustifiably idolized the life of the Hungarian peasants. ${ }^{8}$ He was satisfied and completed the task. An interesting feature of the music is his use of Hungarian folk melodies and symphonic music inspired by them. ${ }^{9}$ He also based a two-part suite for symphony orchestra on the film score. Not long after completing the film music, Lajtha composed his First Symphony op. 24, which he dedicated to Hoellering. So, Lajtha was clearly writing film music and symphonies side by side in those years. In 1990, Melinda Berlász drew attention to motivic similarities between the Hortobágy orchestral suite and the First Symphony. ${ }^{10}$ Just one example is the rhythmic resemblance between the 2 nd

6. András Erszény, nicknamed as “Komor Ló" [Gloomy Horse], is the protagonist of Móricz's short story, through whom the writer again grasps the opportunity to reveal the tough conditions of Hungarian rural life. Zsigmond Móricz, "Komor Ló. A Hortobágy legendája” [Gloomy Horse. The legend of the Hortobágy], Pesti Napló 85/291 (25 December 1934), 65-68.

7. János Breuer refers to a list written by Lajtha at the request of the Hungarian Musicians' Association in 1954, where he defines the genre of Hortobágy as "orchestral pieces for film." Breuer, Fejezetek Lajtha Lászlóról, 186.

8. Ibid., 179.

9. Lajtha began collecting folk music in 1911 only a few years after Bartók and Kodály. Folk music research and editing the collected material remained a major field in his œuvre in the half century up to his death in 1963.

10. Melinda Berlász, "Müfajszerű gondolkodás Lajtha László zeneszerzői életművében” [Generic thinking in the compositional life's work of László Lajtha], Magyar Zene 31/1 (March 1990), 106. 
EXAMPLe $1 \mathrm{~b}$ Symphony no. 1 , mov. 1 , bb. 1-5

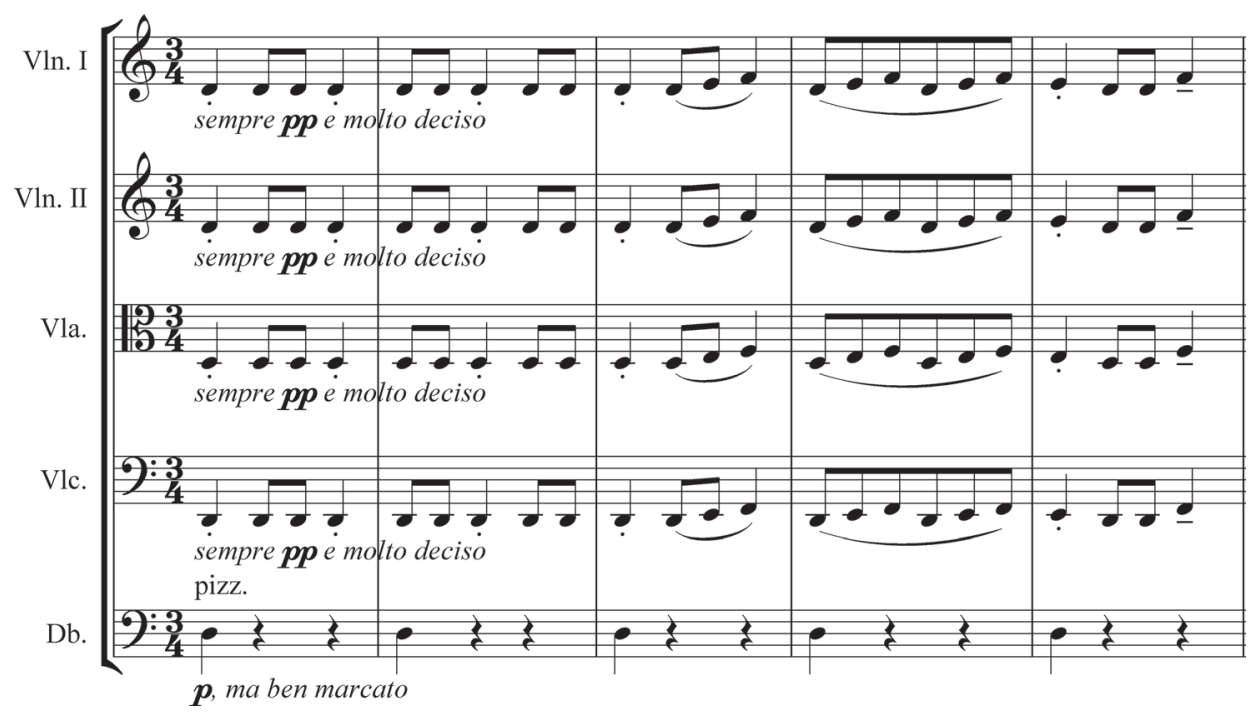

movement of the suite ("Galopard dans le puszta") and the first movement of the First Symphony (compare Examples $1 a$ and $1 b$ ).

Hoellering can be assumed to have been satisfied with Lajtha's work, for in 1947, more than a decade later, he asked for him specifically to compose the music for a further film. Twelve years after T. S. Eliot completed a verse drama in 1935 entitled Murder in the Cathedral based on the martyrdom of St. Thomas Becket, Archbishop of Canterbury, ${ }^{11}$ Hoellering and Eliot planned together to turn it into a movie. The film differs somewhat from the drama, with some new scenes, omission of others, and dramatization of the choral scenes to suit the needs of the new genre. ${ }^{12}$ In 1951, the film won two prizes at the Venice International Film Festival.

On the one hand, the success of the movie drew international attention to Lajtha, on the other, Hoellering's invitation to him to spend a year in London gave him an opportunity to dedicate himself full time to composing. According to Lajtha's reports, he was allowed to compose as he wished. Encased in the film

11. Eliot's drama was premièred in Budapest three years later, on 19 May 1938, in the National Chamber Theater, on the occasion of the 34th International Eucharistic Congress. The original title was changed to a well-sounding but rather didactic The Triumph of Faith. The performance and the piece failed. I have found no mention of any further Hungarian performances in Lajtha's lifetime.

12. A pamphlet was made for the first performance in New York in 1952, containing the text itself and two prefaces, one by Eliot and the other by Hoellering, both summing up the main differences between the original drama and the film adaptation. They outline the problems faced and the solutions found. A copy of the publication is available in the Lajtha Bequest, preserved at the Archives of 20th-21st Century Hungarian Music, Institute of Musicology, Research Centre for the Humanities, Hungarian Academy of Sciences (hereafter referred to as: Lajtha Bequest): T. S. Eliot and George Hoellering, The Film of Murder in the Cathedral (New York: Harcourt, Brace and Company, 1952). 
music are several excerpts from the Third Symphony op. 45 (1948), the Quintet no. 2 op. 46 (1948), the Trio no. 2 op. 47 (1949) and the variations "Les Tentations" op. 44 (1947-1948). The intention behind the composition is often raised as a crucial question. Emőke Tari Solymosi in her doctoral dissertation asserts that Lajtha clearly meant to compose independent pieces for the concert hall, and rejected compromise in the interests of the film. ${ }^{13}$ Solymosi applies her reasoning in the connection with the works mentioned by Lajtha in his statements. She cites Lajtha's letter of 17 January 1948, from London, to the Hungarian musicologist Bence Szabolcsi. There Lajtha wrote: "At first they not only have the music composed, but they also record it, and the pictures as well as the distribution of the lines are already matched to the music." 14 However, Lajtha did not clarify in the letter whether the word "music" refers to a whole movement, a whole symphony or merely a shorter passage. Twelve years later, in 1962, Lajtha sent a note to his co-worker on folklore, Zsuzsanna Erdélyi: "First I wrote the two-part Third Symphony, and only thereafter did Hoellering devise the plot for it." ${ }^{15}$ Here Lajtha makes a more obvious statement, yet it too can easily be misleading. For the film music he uses only excerpts taken from the symphony, often shortened or configured at some points. It is clear that the whole piece is not applied in the film, so that the film is not adapted to Lajtha's Third Symphony or to the Variations - this was unnecessary given the malleability of the musical structure. Still, the scenes must have been fitted by Hoellering and Eliot to the music: not to the whole symphony, but to shorter parts of the completed sections. ${ }^{16}$

The traits of the musical material show that sections used in the film took shape alongside those for the concert hall. Lajtha devised small, adaptable units that might be called mosaics, easily sewn into the scenes like a kind of patchwork, not as strictly compiled musical formulations. They often suggest timelessness: variable speeds of tracking, slow fades in or out, freeze-frame shots allow fine tuning of the visual to the audible. So it was needless to fit the plot itself to the music, but all the more necessary to calibrate precisely the duration of certain scenes.

Musical analysis of the concert-hall pieces reveals that gaining acquaintance with the special shaping required for film music became a source of inspiration

13. Solymosi, Lajtha László színpadi müvei, 296.

14. Lajtha's letter to Bence Szabolcsi, 17 January 1948. First published by György Kroó, "Lajtha László arcképéhez" [To the portrait of László Lajtha], in Lajtha tanár úr. 1892-1992 [Professor Lajtha. 1892-1992], ed. Ildikó Retkesné Szilvássy (Budapest: Liszt Ferenc Zeneművészeti Főiskola, 1992), 50-51.

15. Erdélyi, A kockás füzet, 62.

16. Matching music and film is always a hard task, but illuminating in terms of composition techniques. On various ways of toning the audible to the visual in a film and interferences between concert pieces and film music, see, for instance, Christopher Palmer, "Prokofiev, Eisenstein and Ivan," The Musical Times 132/1778 (April 1991), 179-181; Peter Moormann, "Von der Filmmusik zur Konzertsuite: Semantische Verschiebungen in Sergej Prokofjews Kompositionen zu 'Leutnant Kishe,', Archiv für Musikwissenschaft 69/1 (2012), 42-50; Richard N. Burke, "Film, Narrative, and Shostakovich's Last Quartet," The Musical Quarterly 83/3 (Autumn 1999), 413-429. 
for Lajtha in his late creative period. ${ }^{17}$ The following analysis lists the main similarities in Lajtha's film music and other works. It examines the motivic relations involving the late symphonies, the parallels in ways of constructing the musical form, and the appearance of specific topoi.

The film music consists of fragments from two chamber works and two symphonic pieces (Table 2). Music is prominent in scenes displaying the temptations of Becket - Lajtha uses a symphonic apparatus here. The parts for a chamber apparatus - details of the two chamber works - appear as a melodramatic solution in scenes of present life in Canterbury, accompanying monologues recited by the chorus and a family conversation. The diversity in the two stresses the differences in the disparate dimensions of the plot: the historical, symbolical tragedy of the Archbishop versus the views of the people and everyday Canterbury life. In the play the people appear mainly as a chorus, as in ancient Greek tragedy. The film makes such scenes more dramatic and in a way more personal. This intimacy is underlined in the score by using chamber music.

The largest part of the film music derives from the variations "Les Tentations." It is applied to the scenes displaying the four temptations of the Archbishop. This is evident also through the traditional interpretation of music as a tool of seduction. In the score of the Variations, Lajtha marked August 1947 as the date when he began composing. His first personal meeting with Eliot and consultations on cooperating with him had taken place five months before. In a letter to his wife, Lajtha describes Eliot as "a great person in the English-speaking world," ${ }^{18}$ and gives some details of their first conversation:

17. Here a striking similarity appears with the œuvre of Ralph Vaughan Williams. In 1948, a British film entitled Scott of the Antarctic was made in memory of Captain Robert Falcon Scott, for which Vaughan Williams wrote music that won a prize at the Prague Film Festival, as would Lajtha's film music in Venice three years later. The parallels continue: Vaughan Williams' Symphony no. 7, Sinfonia Antartica, is based on the material for the film and concurrently seen as the beginning of the composers late creative style. Daniel M. Grimley, "Music, Ice, and the 'Geometry of Fear': The Landscapes of Vaughan Williams' 'Sinfonia Antartica'," The Musical Quarterly 91/1-2 (Spring-Summer 2008), 116-150. Documents show that Lajtha thought highly of Vaughan Williams' musical style. On his death, Lajtha gave a lecture recital illustrated with recordings, analyzing Williams' Symphonies Nos. 1, 4, 5, and 6. Here Lajtha referred to his relation to the British composer: "When I became acquainted with Vaughan Williams, who was 20 years older than me, I viewed him not only with reverence and love, but with sympathy, to which he was entitled for the Latin light, and above all the rejuvenation he found in folk music.” John S. Weissmann in a study drew parallels between Lajtha's and Vaughan Williams' symphonic styles. Lajtha's reaction was short, but telling: "You compare me to Vaughan Williams? Rather witty.” Lajtha's letter to Weissmann, 31 July 1959. Lajtha Bequest, shelf mark: MZA-LLScript 8.503:1. The manuscript of the lecture recital can also be found in the Lajtha Bequest; its text appeared in print as well: László Lajtha, "Vaughan Williams," in Lajtha László összegyüjtött írásai [The collected writings of László Lajtha], vol. 1, ed. Melinda Berlász (Budapest: Akadémiai Kiadó, 1992), 282-286.

18. Lajtha's letter to his wife, 29 March 1947. Lajtha Bequest, shelf mark: MZA-LL-Script 8.237:1. On the relations between Lajtha and Eliot, see Melinda Berlász, "László Lajtha and T. S. Eliot," The New Hungarian Quarterly 33/127 (Winter 1992), 163-169. Eliot's reputation in Hungary differed from that of the English-speaking world, being far more negative for political reasons. When he won the Nobel Prize in 1948, the Hungarian daily Népszava published an unsigned article intimating hidden political motives behind the nomination, claiming: "Eliot's œuvre does no good either for progress or for peace." No author, "Thomas Eliot angol költő kapta az 1948-as irodalmi Nobel-díjat" [English poet Thomas Eliot awarded with the 1948 Nobel Prize in Literature] Népszava, 5 November 1948, 4. 
TABLE 2 Musical excerpts used in the film Murder in the Cathedral

\begin{tabular}{|c|l|l|}
\hline & Film scene & Musical excerpt \\
\hline 1. & Main title & Symphony no. 3 op. 45, mov. 2 \\
\hline 2. & Introduction & Symphony no. 3, mov. 2 \\
\hline 3. & Fanfare (Becket meets the King) & Variations op. 44 and Symphony no. 3, mov. 2 \\
\hline 4. & Choral speaking & Quintet no. 2 op. 46, mov. 2 \\
\hline 5. & Becket goes to his room & Variations, intermezzo 1 \\
\hline 6. & First Tempter & Variations, theme and variation 1 \\
\hline 7. & Becket's first soliloquy & Variations, intermezzo 2 \\
\hline 8. & Second Tempter & Variations, variation 3 (fragment) \\
\hline 9. & Becket's second soliloquy & Variations, end of variation 3 and intermezzo 3 \\
\hline 10. & Third Tempter & Variations, variations 4, 5, and 6 \\
\hline 11. & Becket's third soliloquy & Variations, intermezzo 4 \\
\hline 12. & Fourth Tempter & Variations, variations 7, 8, and 10 \\
\hline 13. & $\begin{array}{l}\text { Dramatized chorus scene } \\
\text { family idyll) }\end{array}$ & Trio op. 47, mov. 2 \\
\hline 14. & Arrival of the Knights & Symphony no. 3, mov. 2 \\
\hline 15. & Choral speaking & Quintet no. 2 op. 46, mov. 2 \\
\hline 16. & Becket's death & Symphony no. 3, mov. 1 (clarinet solo) \\
\hline
\end{tabular}

I told him how I envisaged the disposition of the music. How I shaped the music and how my envisaged music shapes the parts of the drama I want to put into music. Eliot first kept quiet - then interrupted me and enthused - and in the end announced: very few understood his poetic intentions so well as I did. [Then he said] modestly and gently: only with your music will the film be true; it will help a lot, and raise up my words, my thoughts, my imaginations. ${ }^{19}$

The meaning of the words that he quoted from Eliot becomes clear as soon as one watches the film. The stationary scenes are really "raised up" by Lajtha's flowing, dramatic music, and the two factors - the visible and the audible - together create a more complex level of possible reception. ${ }^{20}$ The vigorous musical texture and brilliant instrumentation interpret the words of the First Tempter in another, latent dimension, through musical gestures - while dubbing a chess match at the same time. The Second Tempter offers Thomas power and glory. The dramatic actions in the two scenes are quite the same, only the words themselves and the music

19. Lajtha's letter to his wife, 29 March 1947. Lajtha Bequest, shelf mark: MZA-LL-Script 8.237: 1.

20. The same phenomenon - audible and visible effects amplifying each other in different dimensions appears in the third and last cooperation between Lajtha and Hoellering, Shapes and Forms, a silent movie without a story line. During the main title a textual preface is projected, which states among other things: "Aided by the music, the camera will be your guide on this journey through an enchanted world." It was soon clear that the film was to be their last common project. In a letter from 10 April 1952, Lajtha remarks bitterly that Hoellering had not even phoned him or written to him since receiving the score of Shapes and Forms. Lajtha's letter to his sons, 10 April 1952. Lajtha Bequest, shelf mark: MZA-LL-Script 8.343:2. 
making the difference. Lajtha uses brass in the orchestra, marked maestoso, which gives the words of the Second Tempter a notably lavish overtone. The unscrupulous opportunism of the Third Tempter is marked by mobility: motifs moving swiftly to and fro. The Fourth Tempter - who remains invisible and speaks in the voice of T. S. Eliot himself ${ }^{21}-$ is accompanied with a single cor anglais. The effect is uncanny. The use of a solo instrument in a twentieth-century orchestral piece always has a special function, an individualistic meaning. Here the bizarre, slinking, selfish seduction of the cor anglais conveys an almost schizophrenic conversation with the strongest tempter, the Archbishop's merciless struggle with himself. The Fourth Tempter offers him no goods or pleasures of the world, but speaks of the Archbishop's personal wishes and intentions. His words reveal to Thomas that even a seemingly magnanimous move of self-sacrifice can be triggered by vanity or self-conceit. Instead of "what" everything may depend on "why."

The Variations "Les Tentations" fit the film scenes, but they cannot be seen as program music. Without the film, the music functions well as absolute music, needing no extra-musical story line. The individual variations have no titles. ${ }^{22}$ "Les Tentations" is a sparkling symphonic piece displaying Lajtha's brilliant sense of instrumentation and his affinity to musical characters.

Composing for a film raises some essential technical questions. Perhaps Lajtha himself summed up best the cooperation between the three artists from three separate fields: Eliot the writer, Hoellering the film director, and Lajtha the musician. In 1948 Lajtha published in The Chesterian an essay entitled "Music and Films." In the article he wrote:

Thus we get three artistic categories and their representatives: the "film-choreographer" i. e. the producer, the poet or writer, and the musician. They work independently to a certain extent, and also cooperatively. ${ }^{23}$

In a way, the film adaptation of Murder in the Cathedral is a problematic work. A letter in the Lajtha Bequest answers some questions posed by László Lajtha Jr. The letter that the latter had obviously written on his reserves about the Murder is not extant any more, but from Lajtha's reply it can be assumed that the epic style seemed to his son to be the source of the tardiness for which the film had been criticized. In his letter Lajtha defends Eliot's drama from the upcoming accusations:

21. It becomes clear from the preface to the sound-track text published in 1952 in New York that Hoellering first made Eliot record the whole drama on tape. This was one reason why he had later the Fourth Tempter speak in Eliot's voice. T. S. Eliot and George Hoellering, The Film of Murder in the Cathedral, v.

22. Vaughan Williams gave titles to certain parts of his film music Scott of the Antarctic. These motifs are rebuilt symphonically, and although they transmit a kind of narrative, they have no exact meaning in the Seventh Symphony.

23. László Lajtha, "Music and Films,” The Chesterian 23/155 (July 1948), 3. 
The Murder is not an epic work, but a dramatic one. In its original form on stage, it is a mystery play which - performed and staged properly - makes the impression of a good drama. There is nothing epic about it at all. ${ }^{24}$

Lajtha's remark implies that he saw Eliot's drama on stage, otherwise the work could not have evoked such impressions in him. The genre name used by Lajtha - mystery play - often appears in newspaper reports of the succeeding Hungarian première in 1938. In the same letter, writing about film music, Lajtha draws on the definition of dramatic art and applies it to the Murder:

When dramatic tension is truly and deeply staggering emotionally, it reaches a peak of dignity. ... I would be sorry if the music had failed to dominate precisely at the end of the film, for I believe this (the first movement of the Third Symphony) to be music of such a kind. ${ }^{25}$

Lajtha's remark on the nature of mystery plays has great relevance. Eliot's verse drama is not a historical drama in a traditional sense, and the film based on the drama is not a costume movie. Both focus on inner successions of psychological events, perpetual matters, personal types or phenomena standing outside historical time. Irrespective of time or place, the energies aim at transmitting eternal theses, displaying martyrdom as a symbolic ritual. Furthermore, all of this occurs at a remote distance of more than 800 years, which shields the artists comfortably from everyday politics.

In 1948, Lajtha wrote to Bence Szabolcsi about the course of the work:

I do not illustrate or explain anything in the music - Hoellering understood quite well that this was not possible and not needed at all. I am tied to nothing but time. And this - given that music sounds in time - is not an unfamiliar structural principle. ${ }^{26}$

Time as a "structural principle" plays a hugely prominent role in Lajtha's film music and his symphonic works. In the literature, many remarks can be found about the visual inspirations and dramatic intention of his works. Lajtha saw musical forms in the traditional sense - such as the sonata form - rather austere and rigid, and so he shaped the special formal structures of his symphonies through musical solutions based on gestures. This meant that the nature of film music and the attitude of the composer fitted perfectly. Another feature connected to the

24. Lajtha’s letter to his son, László Lajtha Jr, 10 April 1952. Lajtha Bequest, shelf mark: MZA-LL-Script 8.343: 2 .

25. Ibid.

26. Lajtha's letter to Bence Szabolcsi, 17 January 1948. Lajtha tanár úr, 50-51. 
way of shaping the forms and to the question of time can be equally found in the Variations and the Third Symphony: it involves the cutting of short formal units at several logical spots in the musical process. Thus each consistent section of the musical work can be removed from the whole thus becoming adaptable for film music as a kind of replaceable building stone. This phenomenon is also explored in Lajtha's 1948 essay on film music:

\begin{abstract}
My solution was to compose - beginning at the titles - one movement which may be cut at certain places. It is very easy to make music "cuttable." Properly speaking all musical forms, even most of the classical schemes, are "cuttable" since their episodes, etc. are detachable where a new section joins in. All that is required is to compose the music in such a way that at the place of the proposed cutting, a half-bar rest occurs in a bar of commontime. How many times does this happen in symphonic music! $!^{27}$
\end{abstract}

One can agree with Lajtha that most "classical schemes" can be cut, too. The main difference lies in the size of the excisable sections. In a classical movement, the join points can be found after larger sections of form, but with Lajtha's film music such joins follow on at shorter distances.

Such excisable sections can be found, for example, in the first movement of the Third Symphony, where extremely varied musical moods follow swiftly from one another. The clarinet opens the Symphony with a Gregorian-style melody that runs right up to the first join. Suddenly the percussion group comes to the fore, sounding like a thunderstorm, which lends a naturalistic, picturesque mood to the music. After that the strings begin a lyric, dolcissimo melody. Here the traditional distinction of first subject and second subject - despite the difference in characters - is not suitable to describe the music. So in spite of building a traditional sonata form in the first movement of the Symphony, Lajtha's music completes the movement with smaller elements or expressions and almost clearly visual gestures (Example 2).

The other symphonic work used in the film music is a set of variations. It contains many cutting points that relate it to the Symphony. After introducing the theme, the orchestra plays eleven variations, most of them swift or energetic in tempo. They are interspersed with four slower segments that Lajtha marked as Interludes. The musical texture of the first Interlude is intentionally bitty: it could be stopped at several moments of the music. The film music offers a good example of this easily excisable type of material. An interesting variability appears in the scene where the First Tempter tries to sway Becket. The first Interlude is heard first in the scene, after which the appearance of the First Tempter gives way to

27. Lajtha, "Music and Films," 6. 
EXAMPLE 2 Symphony no. 3 , mov. 1, bb. 52-58

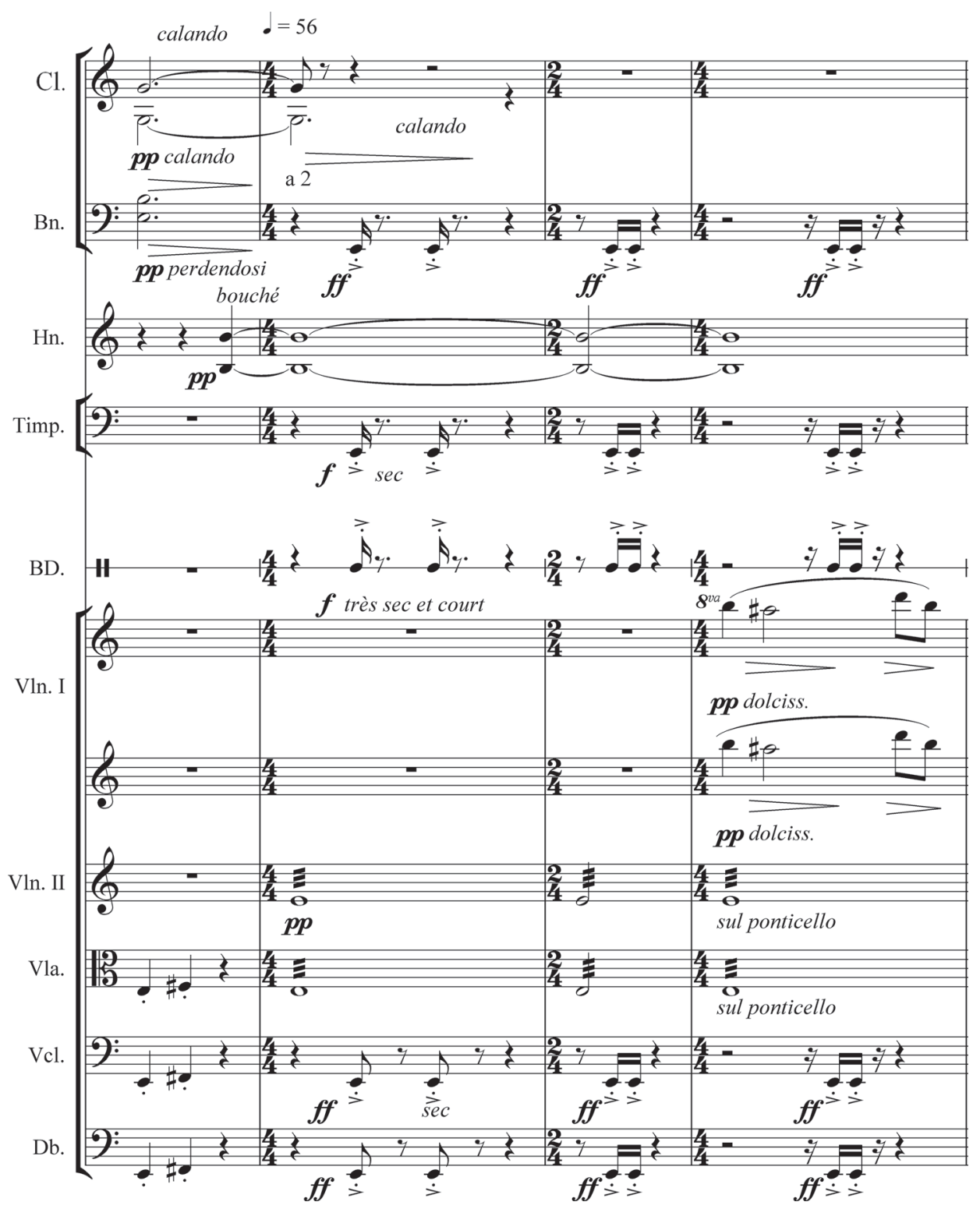

a musical section placed earlier in the score than the Interlude is: the theme of the Variations. The music then continues from where it stopped: the end of the first Interlude. This solution reveals how the excisable sections of Lajtha's music become not only easy to shorten or lengthen, but they are also able to appear in 
more than one thematic order. Within limits, the order of the mosaics is free to changes. Lajtha arrived at these special ways of form building while working as a film-score composer. This experience deeply influenced the style of his late creative period and the structure of his symphonic works (Table 3).

TABLE 3 The formal sections of the beginning of the Variations and their mosaic-like reordering in the film

\begin{tabular}{|l|l|l|l|}
\hline Symphonic piece & theme & interlude 1 & variation 1 \\
\hline Film score & interlude 1 & theme & variation 1 \\
\hline
\end{tabular}

The theme of the Variations is Lajtha's own invention: it is neither a citation from another composer nor one he has already used elsewhere. The melody line bears a resemblance to the second theme in the final movement of the Third Symphony - another sign of the common root of the symphonic music and the film music. The ambitus of the two motifs covers the tones of a seventh chord (Examples $3 a$ and $3 b$ ).

Example 3a Theme of the variations "Les Tentations"

Vln. I

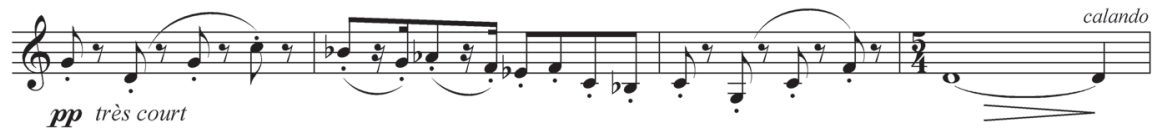

EXAMPle 3b Symphony no. 3, mov. 2, bb. 40-46 (the second theme)

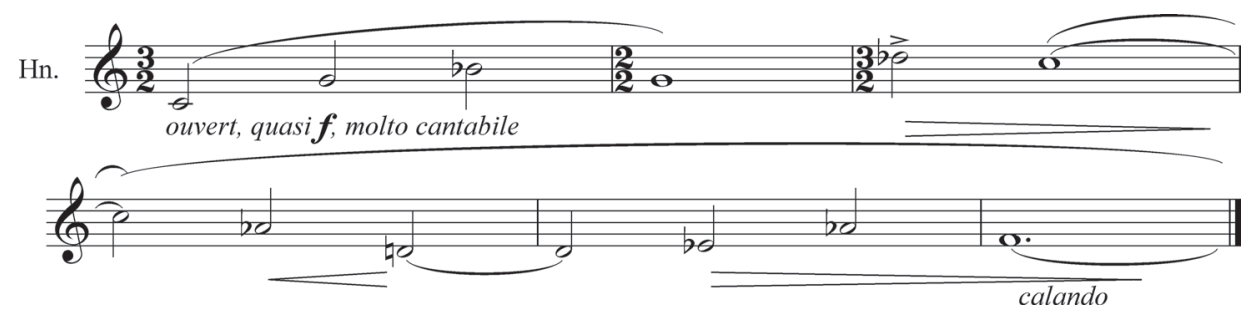

The downward thirds at the beginning of the first movement of the Third Symphony show more than a slight resemblance to a frequent motif in the Variations. In the film, this part of the Variations accompanies the monologues of Thomas as a kind of leitmotif (Example 4a). The opening clarinet solo from the Symphony with the downward thirds is joined in the film to the death of the Archbishop, where Thomas lies on the floor in his own blood, killed by the four knights (Example 4b). 
EXAMPLE 4a Variations, interlude 1

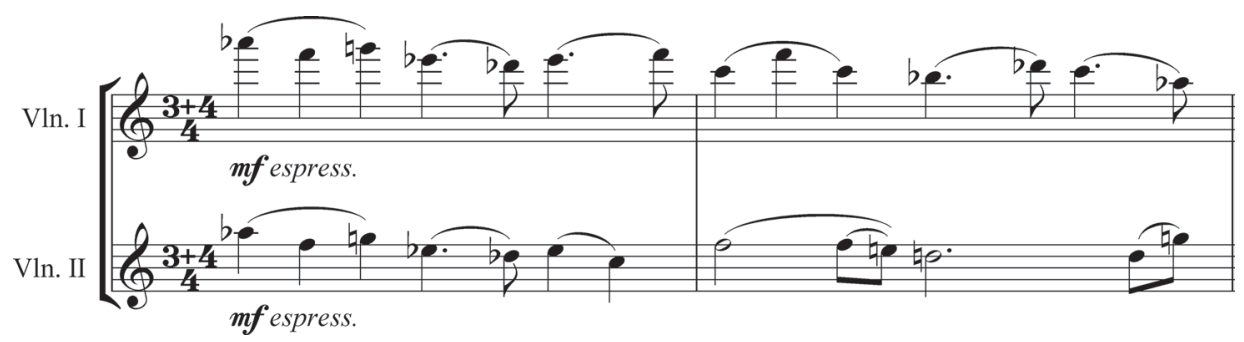

EXAMPLE 4b Symphony no. 3, mov. 1

Cl.

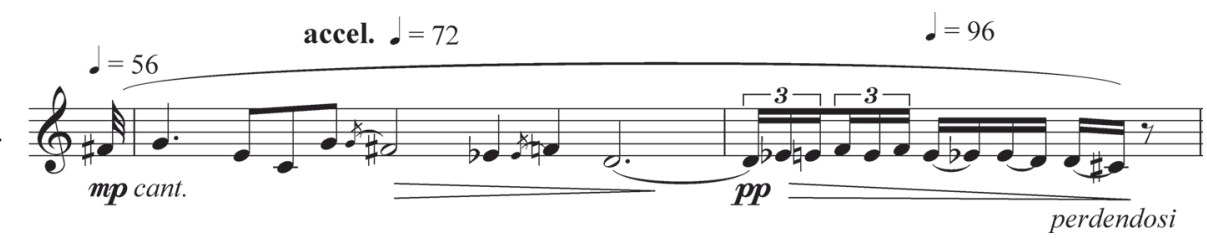

The common inspiration is apparent not merely in the way the musical form is shaped or the community of the melodic source in the Variations and the symphonies. Some other compositional solutions also lean toward the symphony cycle of the late period. The remaining part of this study examines some of the typical characteristics of these works.

Several spots of the Third Symphony used in the film music are strongly linked to the symphony cycle of the late period. The chorale at the end of the first movement infiltrates as a topos in Lajtha's late style, reappearing in the Symphonies Nos. 5, 7, 8, and 9. Although it has no programmatic meaning, it triggers firm associations, while conveying a general meaning in line with Eliot's concept. As Lajtha wrote of the final choral section:

I cannot repeat enough how far I was from composing program music, yet it was an English saint, Thomas Becket, who prayed in Transylvanian style. (The first movement of the Third Symphony is a Székely chorale.) The film has the same music. ${ }^{28}$

The chorale in the Symphony is followed by a material in sixteenth notes. In the later symphonies this texture becomes a topos, outlining the discernible profile of Lajtha's war music. In the film, it appears at the beginning, during the main titles, and on the arrival of the four knights, both scenes being accompanied by motoric, pulsating music. 
The third topos alongside the chorale melodies and motoric music is an instrumental solo that emerges from the orchestral tutti in various lengths. This solution is found in the Variations and in the texture of the Third Symphony. As for the film scenes, the instrumental solo plays a major part in Becket's soliloquies. After the exit of the First Tempter, the violin solo from the second Interlude of the Variations is heard. A violin solo also appears at the end of the first movement of the Third Symphony and at the end of the film, after the chorus ends its prayer. Such a solo emerging from an orchestral texture plays a major role in the music of Lajtha's late symphonies, appearing in the Seventh, Eighth, and Ninth Symphonies, each time emphasizing subjectivity. The structure of the violin solo in Symphony no. 8, a rising melody that ultimately fades to nothing, resembles the one in the second interlude of the Variations, accompanying the weary pensiveness of the Archbishop's soliloquy. The configuration of the musical topos depicts a "tragic hero" in the musical narrative.

To conclude let us recall Lajtha's paper of 1948. There he expresses disapproval of the kind of film music that simply serves film purposes. Lajtha believed in the existence of film music as a kind of classical music, not just a "commercial" genre. ${ }^{29}$ For an example of the scope in it, he mentioned the working process of Murder in the Cathedral. Although Lajtha relied on his own experience to voice his opinion, this kind of film-music making was not unique in the 20th century. One can refer to film scores by Shostakovich, Prokofiev or Vaughan Williams. So Lajtha was joining a quite frequent branch of musical practice in his era, inspired by genres that would strongly influence his late creative style. It was a lucky accident that he could base his symphonic experience on film music, and this encounter predestined the main features of his succeeding symphony cycle. 
